\title{
Based on an Almost True Story: Providing Real Life Protection to REAL LIFE CHARACTERS
}

\author{
Brandy S. Ringer \\ Volume XIII - Fall 2012
}

\section{INTRODUCTION}

In our society, Hollywood is depicted as a glamorous industry that has perpetual stability and unlimited potential for wealth. However, in reality, the filmmaking industry is one of the riskiest ventures for an investor. A film production company must overcome a series of obstacles just to produce the film and faces even more challenges after its completion. The greatest challenge in any filmmaking project is predicting whether the project will be successful and if so, to what extent. A film production company cannot predict a project's success by adhering to a clear set of rules. Rather, the investors and film production companies must rely on core guidelines and contemporary trends to speculate whether a particular film will be successful.

The "little black dress" of filmmaking - the genre that will never go out of style - is a film based on a true story. These films have withstood the test of time and film trends to remain successful on many levels, ranging from independent films to films produced by major production companies. While the allure of films based upon true stories is unclear, it may be related to the fact that many of these true stories received public attention prior to the film. Thus, people are already engaged in the story and want to see first-hand how the situation unfolded. 
The public interest is what makes the story valuable and creates the incentive for film production companies and investors to take the risk in creating the film. ${ }^{1}$

Given that the film's value rests on its factual nature, it is important that the truthful character of the screenplay and the portrayal of the characters is maintained. Many films that are "based on a true story" have received criticism for factual and historical inaccuracies or for poor adaptations and portrayals of the characters. ${ }^{2}$ In addition to tainting the truthfulness and veracity of these stories, many real-life individuals are also harmed through the depictions of their character in the film. This often leads to litigation, with inconsistent outcomes, thus leaving production companies and the subjects of nonfiction films unclear as to their legal rights. In order to preserve the value and allure of nonfiction works, the rights of film production companies to engage in creative freedom with the stories must be curtailed.

This note will focus on how the film producer generally obtains the exclusive right "to change, modify and rearrange the [story] while the Picture is created," 3 thereby depriving the original author or subject of the story of control over their story and failing to provide an adequate recourse when an inaccurate adaptation damages the reputation of one of the characters. This note will then evaluate the shortcomings of current remedial measures. With the findings from this evaluation, the note will conclude with my recommendations.

\footnotetext{
${ }^{1}$ Michelle E. Lentzner, Note, My Life, My Story, Right? Fashioning Life Story Rights in the Motion Picture Industry, 12 HASTINGS COMM. \& ENT. L.J. 627, 628 (1990).

${ }^{2}$ Examples include: ERIN Brockovich (Jersey Films 2000), The PERFECT STORM (Warner Bros. Pictures 2000), MiLK (Focus Features 2008), THE KING'S SPEECH (The Weinstein Company 2010), and THE BLINDSIDE (Alcon Entertainment 2009).

${ }^{3}$ Daniel M. Satorious, From Book to Screen: Mining Literary Works in the Movie Business, 24 SPG ENT. \& SPORTS LAW 1, 33 (2006).
} 


\section{The Foundation: The AgreEMENT}

In order to create a film based upon a true story, the film production company must acquire the right to the story. ${ }^{4}$ Generally, this is done either by obtaining an option agreement or by purchasing the rights to the story. ${ }^{5}$ Acquiring the rights to the story is important because it protects the film production company from lawsuits for copyright infringement. It also shields the company from the loss of investment that could arise in the event that another production company creates a film based on the same story. However, while the production company receives protection from litigation and potential competition, what protection does the owner of the story receive from the option agreement or from the purchase?

\section{A. Shortcomings of Option and Purchase Agreements}

\section{Perpetual and Irrevocable Rights}

An option agreement is the granting of a work to a producer for a set period of time, known as the option period. ${ }^{6}$ During this period of time, the film producer has the exclusive option to develop the project. ${ }^{7}$ By entering into the option agreement, the production company pays for the exclusivity of developing the project without having to worry that competitors may develop it first. At the end of the option period, the producer must either enter into a purchase agreement with the owner and commence production of the film or allow the option to expire, thereby enabling other producers to acquire the rights to develop the project. ${ }^{8}$

If the production company elects to enter into a purchase agreement, it generally acquires

\footnotetext{
${ }^{4}$ For the purposes of this note, "story" represents the basis of the film, whether it is acquired in the form of a story as told by a subject or individual with first-hand knowledge, as covered in a news casting, or whether it has been memorialized in a book.

${ }^{5}$ Alison S. Cohen, PLI Outline - The Development of Feature Films, in COUNSELING CLIENTS IN THE ENTERTAINMENT INDUSTRY 681-92 (2009).

${ }^{6}$ Satorious, supra note 3 , at 33.

${ }^{7}$ Id.

${ }^{8}$ Cohen, supra note 5, at 682.
} 
the exclusive and perpetual rights to the work. ${ }^{9}$ Standard purchase agreements generally grant the production company the exclusive and perpetual "rights in the plot, theme, title, story and characters in the picture..." and the "right to make sequels, mini-series and remakes." result, unless the owner specifically reserves the rights to future works, the owner loses the potential for future projects. This is one area in which the owner does not receive protection from the standard practices.

\section{Exclusive Rights}

While negotiations for option and purchase agreements are standard in most respects, the negotiation process for nonfiction work differs slightly and requires additional considerations. Among these considerations are the degree and the scope of rights to be granted to the production company. All option and purchase agreements consider the degree of rights to be granted, however, with nonfiction works, the option must consider the scope of the rights because there are more rights at issue and there are more individuals' rights at issue.

In regards to the owner's rights, there is more to consider than just granting the rights to a particular project. With most nonfiction stories, the owner does not want to convey the rights to his entire life, but rather, the owner is interested in granting the rights to a particular period of his life or to a specific event. ${ }^{11}$ The owner must carefully negotiate and convey only those rights that he intends to convey to protect his interests in the story or in his life. This may also involve negotiations regarding the duration of the agreement in order to prevent overreaching. The owner must protect his interests at this stage of negotiation process because the standard agreements used in the film industry do not protect the owner's interests.

\footnotetext{
${ }^{9}$ Satorius, supra note 3 , at 33

${ }^{10} \mathrm{Id}$.

${ }^{11}$ Cohen, supra note 5, at 685.
} 
In addition, in a nonfiction work, it is likely that there are other individuals portrayed in the work that may have rights at stake. This includes supporting characters, ancillary characters, and perhaps institutions. In order to prevent future legal issues, the production company may consider obtaining these individuals' rights through a release. ${ }^{12}$ Although production companies are encouraged to obtain releases from all individuals, ${ }^{13}$ these contracts are expensive,${ }^{14}$ and therefore, unattractive to the production companies.

In addition to negotiating the duration of the agreement to prevent overreaching, the owner must also negotiate the scope of the rights that he is conveying. Again, this type of agreement will limit the potential for loss of future projects. Therefore, the owner must negotiate to protect his interests given that the standard agreements used in the film industry do not do so.

\section{Creative Freedom}

The option and purchase agreement for a nonfiction work must also consider the production company's ability to take liberties with the factual representations in the screenplay. ${ }^{15}$ This point of contention is arguably the most important part of the negotiations for a nonfiction work. The importance of this negotiation stems from the conflict that is created by the relationship between the film production company and the owner of the work.

The conflict arises because the production company has an interest in obtaining the highest degree of control over the project in order to maximize their interests. In an effort to

\footnotetext{
${ }^{12}$ This note will not discuss the scenario in which the production company fails to obtain consent releases from the additional characters. However, it is important to note that if the production company does not obtain a release and portrays the character without permission, these characters may seek to obtain relief through Right of Publicity laws. The Right of Publicity permits individuals to control the use of their name/likeness in commercial uses. This will be discussed in greater detail in a later section of this note.

${ }^{13}$ Jacqui Gold Grunfeld, Docudramas: The Legality of Producing Fact-Based Dramas - What Every Producer's Attorney Should Know, 14 HASTINGS COMM. \& ENT. L.J. 483, 528 (1992).

${ }^{14}$ Id. at 530; see also Susan Hallander, A Call for the End of the False Light Invasion of Privacy Action as it Relates to Docudramas, 15 SETON HAll J. SPORTS \& ENT. L. 275, 276 (2005).

${ }^{15}$ Cohen, supra note 5, at 684 .
} 
create a more marketable and entertaining project, the production company seeks to obtain the rights to take liberties with the facts. The more control the production company has, the greater the opportunity for profit. However, the more control the production company has over the portrayal of the events, the greater the risk of diminished authenticity. Conversely, the owner of the work seeks to retain a degree of control over the project to ensure the accuracy of the facts, his vision for the project and the accuracy in the portrayal of the characters.

Customarily, in conflicts between the interests of the owner and the interests of the film production company, the owner's interests are superseded, and the film production companies receive the right to "creative control over and complete discretion in the alteration of the story in adapting the story for the screen."16 This includes "the right to change, modify and rearrange the book while the Picture is created." ${ }^{, 17}$ However, there is an existing debate over whether this right is limitless.

As Douglas Y'Barbo wrote in his 1998 article, "if a movie was ever made that was a faithful adaptation of the book, it would only be because the novelist wrote the screenplay, starred in it, produced it, directed it, funded it, and distributed it." ${ }^{\prime 18}$ In the Disney movie, $U p$ Close and Personal, the production company not only changed and modified the biography on which the movie was based, but it also engaged in an "abstraction of the original novel, reworked for mass appeal" that barely left any remnants of the actual story. ${ }^{19}$ By the end of the film, Disney achieved its goal of producing a "feel good" film for their audience, but there was hardly

\footnotetext{
${ }^{16}$ Satorious, supra note 3 , at 34.

${ }^{17} \mathrm{Id}$. at 33.

${ }^{18}$ Douglas Y'Barbo, Aesthetic Ambition Versus Commercial Appeal: Adapting Novels to Film and the Copyright Law, 10 St. ThOMAS L. ReV. 299, 354 (1998).

${ }^{19} I d$.
} 
a trace of the actual character. ${ }^{20}$ Even in less egregious instances of adaptations, at what point should a film production company be limited in their abilities to adapt the film?

The courts have routinely looked to the contract terms of the option agreement to determine the production company's degree of discretion. ${ }^{21}$ However, courts have been generous in allowing creativity and freedom of expression on the part of the production company. Many courts credit this allowance for creativity as a First Amendment right. ${ }^{22}$ Without discounting the importance of First Amendment rights, it is important to consider the impact of creative freedom on the subjects of the film.

\section{B. Protection of the Characters}

\section{Purpose of First Amendment Rights and Intellectual Property Law}

In the 2008 biographical film, Milk, ${ }^{23}$ the film portrayed the first openly gay politician, Harvey Milk, and his struggles to become elected to the San Francisco Board of Supervisors. ${ }^{24}$ In the film, Daniel White, who was convicted of killing Harvey Milk, was portrayed as the villain who struggled with his sexuality. The movie suggested that White's motive for killing Milk was a result of White's struggle with homosexuality. ${ }^{25}$ However, this portrayal is inaccurate based on historical documents and furthermore, it ignores White's political support of Milk and the land-use issue that ultimately led to the demise of their friendship. ${ }^{26}$ Although the

\footnotetext{
${ }^{20} I d$. at 353 .

${ }^{21}$ Davis v. Costa-Gavras, 580 F. Supp. 1082, 1097-98 (S.D.N.Y. 1984) (holding that an assignment of "exclusive, absolute, and unlimited" discretion gave the film production company controlling rights).

${ }^{22}$ The concerns and interests of First Amendment Rights are discussed in Part (II)(B)(2).

${ }^{23}$ Milk, InTERNET MOVIE DATABASE, http://www.imdb.com/title/tt1013753/ (last visited Nov. 2, 2012).

${ }^{24}$ Will O’Bryan, Milk: The Man, The Movie, METRO WEEKLY (Nov. 20, 2008, 12:00 AM), http://www.metroweekly.com/feature/?ak=3917.

${ }^{25}$ John Geluardi, Dan White's Motive More About Betrayal Than Homophobia, SF WEEKLY (Jan. 30, 2008), http://www.sfweekly.com/2008-01-30/news/white-in-milk/.

${ }^{26} I d$.
} 
adaptation in Milk is minor, it highlights a flaw in the current approach to the protection of characters in nonfiction films.

Courts often state that First Amendment considerations outweigh the minor fictionalization of a fact or an event. ${ }^{27}$ The rationale is that the production companies should have latitude in the way they tell the story, primarily because of the freedom of speech granted by the First Amendment. ${ }^{28}$ The courts' protection and encouragement of the production company's creativity echoes the rationale behind intellectual property law. Intellectual property law is intended to reward creativity to increase the amount and quality of products available to consumers. ${ }^{29}$

While fostering creativity is undoubtedly important, especially in the film industry, permitting variations on the factual representations in nonfiction works does not necessarily further the goals of the First Amendment or intellectual property law. This is no more apparent than in films such as Milk or the widely acclaimed, The King's Speech. ${ }^{30}$

The King's Speech is centered on King George VI and his debilitating stutter. In the film, the King's stutter is embellished for climatic effect. While the purpose of this adaptation is primarily for artistic and dramatic effects and although this adaptation has a negligible impact on the portrayal of King George VI, there are other negligible inaccuracies that raise questions of the purposes of the inaccuracies. For instance, the film claims that the King's stutter manifested

\footnotetext{
${ }^{27}$ Relying on the precedent established in Time, Inc. v. Hill, 385 U.S. 374 (1967).

${ }^{28}$ Matthew Stohl, False Light Invasion of Privacy in Docudramas: The Oxymoron Which Must be Solved, 35 AKRON L. REV. 251, 270 (2002).

${ }^{29}$ U.S. CONST. art. I, $\S 8$, cl. 8 ("To promote the Progress of Science and useful Arts").

${ }^{30}$ The King's Speech, INTERNET MOVIE DATABASE, http://www.imdb.com/title/tt1504320/ (last visited Nov. 2, 2012).
} 
itself when he was four or five years old when in fact, the stutter appeared when he was eight years old. ${ }^{31}$ It is difficult to determine what creativity is fostered by this factual inaccuracy.

In Milk and The King's Speech, factual deviations do not further the goal of progressing the arts. While one could argue that the inaccuracies are insignificant, it is important to consider the following question: when does an inaccuracy become significant? Drawing a line is nearly impossible. Without limiting a production company's ability to depart from the facts of a nonfiction work, we quickly embark on a path down the infamous slippery slope that will diminish the rights of those portrayed in the movies.

\section{Issues with Current Remedial Measures}

Even if the subject of a film is harmed by an inaccurate portrayal, the vehicles available to remedy the harm are insufficient. Not only are the avenues for relief difficult and laden with obstacles, but the relief granted is often trivial. A plaintiff has never successfully enforced the removal or editing of an offensive film. At most, a disclaimer has been added to the beginning or ending of the film or minor compensatory damages are awarded. ${ }^{32}$ Thus, the characters who suffer injuries from inaccurate portrayals are left without an adequate recourse. As it currently stands, an injured subject may seek redress through defamation or right of privacy.

\footnotetext{
${ }^{31}$ Laura Prudom, How Accurate is 'The King's Speech'?, MovIEFONE (Feb. 4, 2011, 4:00 PM), http://blog.moviefone.com/2011/02/04/the-kings-speech-fact-vs-fiction/.

${ }^{32}$ Stohl, supra note 28, at n.9 ("The standard disclaimer - which stated that certain events and characters 'have been composited or invented, and a number of incidents fictionalized' - had been moved from the closing credits to the beginning of the movie").
} 


\section{a. Defamation}

The subject of an inaccurate portrayal may pursue a defamation action by alleging that the "forms of speech are false, have caused damage to reputation or emotional distress, have presented a person in false light, or have resulted in criticism, dishonor, or condemnation of any person." ${ }^{33}$ However, this course of action has proved to be very difficult. In order to succeed on a defamation action, the subject must prove:

(a) a false and defamatory statement concerning another;

(b) an unprivileged publication to a third party;

(c) fault amounting at least to negligence on the part of the publisher; and

(d) either actionability of the statement irrespective of special harm or the existence of special harm caused by the publication. ${ }^{34}$

The First Amendment poses the greatest challenged in proving these four components in the context of a nonfiction film. Since the landmark decision in New York Times Co. v. Sullivan, ${ }^{35}$ the Court has struggled to determine and apply "the proper accommodation between the law of defamation and the freedoms of speech and press protected by the First Amendment."36 Consequently, courts have, sometimes unfairly, held that the plaintiff's interests must "give way to the countervailing interest of the defendant in exercising her First Amendment rights ... [because] the type of speech at issue or the interest in limiting the chilling effect of potential liability for speech outweighs the reputational harm to the plaintiff."37

The subject of a nonfiction film that challenges their character's depiction will rarely overcome the First Amendment because courts have routinely provided great artistic leeway and protection to films which are close to the facts. Moreover, the courts have granted greater

\footnotetext{
3328 U.S.C. $\$ 4101$ (2006 \& Supp. IV 2010).

${ }^{34}$ RESTATEMENT (SECOND) OF TORTS $\$ 559$ (1977).

${ }^{35}$ New York Times Co. v. Sullivan, 376 U.S. 254 (1964).

${ }^{36}$ Gertz v. Robert Welch, Inc., 418 U.S. 323, 325 (1974).

${ }^{37}$ Laura A. Heymann, The Law of Reputation and the Interest of the Audience, 52 B.C. L. REV. 1341, 1378-79 (2011).
} 
leeway and protection to portrayals of public officials or public figures. ${ }^{38}$ The courts have justified these separate standards through an argument that public figures "enjoy greater access to channels of communication, and as a result, have a better opportunity to counteract false statements." ${ }^{39}$ Since most, if not all, of the films based on a true story include a public figure, the courts have effectively limited the means available for an individual to "vindicate his good name" and reduced his opportunity to obtain "redress for harm caused by such [defamatory] statements." 40

The impact of the leeway granted to film production companies is evident. For instance, the most difficult component to prove in a defamation action is section (c): fault amounting at least to negligence on the part of the publisher. ${ }^{41}$ Section (c) requires the subject to prove that the film production company inaccurately portrayed the character through a false or defamatory statement with malice or with "knowledge that it was false or with reckless disregard of whether it was false or not." ${ }^{42}$ Demonstrating malice or knowledge is difficult to prove in any context but it is even more difficult to prove when the film production company has an easy defense. For defamation claims, so long as "the 'gist' or 'sting' of the communication is shown to be true," the defamatory inaccuracy will be disregarded. ${ }^{43}$ The subject's burden of proof in this regard is insurmountable.

\footnotetext{
${ }^{38}$ Sean. C. Symsek, Based Upon a True Story: The Tension Between the First Amendment and a Person's Reputation, 10 UCLA ENT. L. REV. 171, 204-05 (2003) ("Where the work is found to be closest to fact, the First Amendment will reign, and the creator's work will be protected.... If the person [depicted] is a public official or public figure, then he or she is harder to defame, giving filmmakers greater artistic leeway to depict such persons about whom society is most interested in learning. The proposed cause of action is drawn very narrowly to afford First Amendment protection for creative freedom").

${ }^{39} I d$. at 178.

${ }^{40}$ Milkovich v. Laorain Journal Co., 497 U.S. 1, 12 (1990) (stating that defamation law developed "not only as a means of allowing an individual to vindicate his good name, but also for the purpose of obtaining redress for harm caused by such statements").

${ }^{41}$ RESTATEMENT (SECOND) OF TORTS $§ 559$ (1977).

${ }^{42}$ New York Times Co. v. Sullivan, 376 U.S. 254 (1964).

${ }^{43}$ Schiavone Constr. Co. v. Time, Inc., 847 F.2d 1069, 1084 (3d Cir. 1988).
} 
Another challenge that a subject must face is proving harm as a result of the defamation.

As a legal matter, an individual suffers harm from defamation when the statement has a deleterious effect on the individual's reputation. ${ }^{44}$ Because an individual's reputation is subjective, and is a social creation resulting from "the collective act of judging another," 45 the difficulty lies in establishing that the subject's reputation was harmed. Without any concrete examples of harm, such as a loss of endorsement, the subjective nature of reputation will be very challenging to prove.

Aside from the challenges and low success rates, defamation actions are not appropriate vehicles for redress in many situations. One glaring issue is that a defamation cause of action is "available only to living people and not their heirs."46 This is problematic as it severely limits the protections available to an individual's name and goodwill. Combining the ancillary challenges with the First Amendment and burden of proof difficulties, it is clear that a defamation action does not adequately protect an individual who is inaccurately depicted in a film.

\section{b. Right of Privacy}

Aside from defamation, a subject may look to the Right of Privacy, and more specifically, what is "commonly referred to as false-light invasion of privacy and is the type implicated in life story rights controversies." ${ }^{47}$ The famous William Prosser coined false-light invasion of privacy as one of the four species of privacy law. ${ }^{48}$ An action in false-light invasion

\footnotetext{
${ }^{44}$ Heymann, supra note 37 , at 1350 .

${ }^{45}$ Id. at 1342.

${ }^{46}$ Daphne Barak-Erez, The Law of Historical Films: In the Aftermath of Jenin, Jenin, 16 S. CAL. INTERDISC. L.J. 495, 500 (2007).

${ }^{47}$ See Lentzner, supra note 1 , at 650.

${ }^{48}$ Nat Stern, Creating a New Tort for Wrongful Misrepresentation of Character, 53 U. KAN. L. REV. 81, 88 (2004); see also William L. Prosser, Privacy, 48 CALIF. L. REV. 383 (1960).
} 
of privacy focuses on the "anguish suffered due to 'highly offensive' false light" rather than the "damage to reputation" that is the focus of defamation actions. ${ }^{49}$ In order to succeed on a falselight claim, the subject must satisfy a three-pronged test:

(1) He must demonstrate that he has been portrayed in a false light;

(2) He must show that the light in which he is portrayed would be highly offensive to a reasonable person; and

(3) He must show that his right to privacy outweighs the defendant's First Amendment Rights. $^{50}$

The challenges of succeeding on a false-light claim are very similar to the challenges associated with defamation actions. The first challenge is proving the first prong - portrayal in a false light. This element is very difficult to prove because like "reputation" in a defamation action, false light is very difficult to define and understand. ${ }^{51}$ Many times, the court places an emphasis on the degree of fictionalization. ${ }^{52}$ Other courts decide false light cases based upon the similarities and dissimilarities of the character as portrayed compared to the actual subject on whom the character is based. ${ }^{53}$ If the altered depiction of the character is the result of minor inaccuracies or minor embellishments, the courts have held that the altered depiction amounts to "creative license for the purpose of telling a compelling and entertaining story.",54

Proving the second prong is equally as difficult because of the subjectivity problems that are inherent in the "reasonable person" standard. This permits the court to exercise discretion and does not provide a reliable standard for the subject to rely upon, nor does it provide predictable protection or redress to the subject. Nevertheless, even if the subject is able to prove that the portrayal would be offensive to a reasonable person, the film production company is

\footnotetext{
${ }^{49}$ Stern, supra note 48 , at 90.

${ }^{50}$ Hallander, supra note 14, at 286; RESTATEMENT (SECOND) OF TORTS $§ 652(\mathrm{E})$ (1976).

${ }^{51}$ Hallander, supra note 14, at 281 (citing Flowers v. Carville, 310 F.3d 1118, 1132 (9th Cir. 2002) ("Judges and legal scholars have puzzled over [false light's] existence")).

${ }^{52}$ Lentzner, supra note 1 , at 653.

${ }^{53}$ Bernstein v. Nat'l Broad. Co., 129 F. Supp. 817, 835-37 (D.D.C. 1955).

${ }^{54}$ Hallander, supra note 14, at 287 (citing Seale v. Gramercy Pictures, 964 F. Supp. 918, 919-20 (E.D. Pa. 1997)).
} 
protected by the actual malice standard and the subject must show "knowing falsity or recklessness under the actual malice standard." ${ }^{, 55}$ Again, it is unlikely that a subject can satisfy all three prongs, thereby leaving him with limited or no recourse.

\section{RECOMMENDATIONS}

As illustrated in this note, the subjects of nonfiction films possess few options for protection from inaccurate portrayals. There are even fewer options when it comes to remedying the harms caused by the inaccurate portrayals. In order to provide more protection to the subjects of nonfiction films, I propose three courses of action to supplant the current system.

First, I propose that the rights to a subject's life be treated as intellectual property. Although some scholars have suggested that reputation be treated as property law, ${ }^{56}$ application of property law is inappropriate for several reasons. First, property law relates to tangible things. An individual's reputation or life story is not a tangible object and thus, property law would not be best suited to handle these matters. In addition, property law is outdated and relies upon common law principles. Instead of forcing a round peg in a square hole, the law regarding reputation and life stories needs to evolve to match contemporary law.

In order to provide better protection to the subjects portrayed in nonfiction films, there must be restrictions on the degree of rights that can be contracted away. At the outset, the owner of the rights to the story should not be permitted to grant the rights of any other individual to the production company. This includes the portrayal of a character in the film or any facts relating to a particular character in the film. This will eliminate the possibility that a subject will unexpectedly discover that he is portrayed in a film and will also encourage contractual

\footnotetext{
${ }^{55} I d$. at 291.

${ }^{56}$ See Heymann, supra note 36, at 1366.
} 
relationships between the film production company and all subjects of a film. Encouraging contractual relationships will foster protection of the owner's rights as well as the First Amendment rights of the film production company. Since contracts supersede First Amendment rights, ${ }^{57}$ the parties may bargain for a contract that will appease both of their interests and will limit or prevent infringement of either party's rights.

Moreover, the owner of the rights should only be permitted to grant exclusive rights in a film for a period of thirty-five years from the date of the purchase agreement. This will provide the film production company with a period of exclusivity that will be sufficient to permit the producers to complete the project, enjoy the financial benefits from the project while it is relevant in pop culture, and even have the opportunity to commence a sequel or mini-series. Any and all projects that are commenced prior to the thirty-five year mark will be permitted to be carried through to completion so long as they are completed within three years from the date of the proposal. The film production company may negotiate extensions with the owner at the conclusion of the thirty-five year period of exclusivity.

Intellectual property law, rather than property law, is the best model for this proposal. In property law, once rights are transferred away, the original owner cannot regain possession without repurchasing the rights from the succeeding owner. ${ }^{58}$ However, intellectual property law has an existing framework available for implementing this solution. Under $\S 101$ of the Copyright Act, ${ }^{59}$ the owner of a copyrighted work can transfer his ownership interests through an "assignment, mortgage, exclusive license, or any other conveyance...."60 The contracts between the owner and the film production company would have to be modified from the purchase

\footnotetext{
${ }^{57}$ Lentzner, supra note 1 , at 636.

58 There are exceptions to this - transfers in fee simple determinable, fee simple on condition subsequent, life estate, etc.

${ }^{59} 17$ U.S.C. $\$ 101$ (2006 \& Supp. IV 2010).

${ }^{60} \mathrm{Id}$.
} 
agreement to an exclusive license in the work. However, both the owner and the production company will be granting and receiving the same general benefits: the owner will be granting rights to the work to the production company and the production company will be receiving the exclusive rights to the work. Moreover, the two sides can contract for more or less rights.

The major difference between the purchase agreement and the exclusive license is the owner's options for the future. Under an exclusive license, the owner of the work may re-gain ownership of the work after a set period of time. ${ }^{61}$ Specifically, the owner may terminate a transfer during a five-year window, beginning at the end of thirty-five years from execution of the grant. ${ }^{62}$

Permitting the owner to terminate the transfer will benefit both the owner and the production company. The production company will receive the benefit of exclusivity during the license period. The owner will benefit because this will allow him to have a second opportunity to either work on his own project or to transfer the rights to another producer. Having the opportunity to reclaim rights to the story or work will also give the owner the opportunity to resolve any inconsistencies or false portrayals of the subjects through additional works.

Furthermore, under $\S 304$ of the Copyright Act, the heirs and other members of an individual's family are permitted to terminate the license. ${ }^{63}$ This is very important for the families of the deceased individuals who are falsely portrayed, ${ }^{64}$ and will enable the family of the

\footnotetext{
${ }^{61}$ Under the Copyright Act, works made prior to 1978 are statutorily treated differently than works made post-1978. See 17 U.S.C. § 304(c) and 17 U.S.C. § 203, respectively. For purposes of this article, I will be focusing on works made post-1978.

6217 U.S.C. $\$ 203$ (2006 \& Supp. IV 2010) (notice must be given not less than 2 years and not more than 10 years before termination).

${ }^{63} 17$ U.S.C. $\$ 304(\mathrm{a})(4)(\mathrm{B})(\mathrm{c})$ (2000 \& Supp. II 2002).

${ }^{64}$ See Jordan Tabach-Bank, Missing the Right of Publicity Boat: How Tyne v. Time Warner Entertainment Co. Threatens to "Sink" the First Amendment, 24 LOY. L.A. ENT. L. REv. 247, 273 (2004) (In Tyne v. Time Warner Entertainment Co., 336 F.3d 1286 (11th Cir. 2003), the district court would not permit the children of the deceased captain depicted in the film "The Perfect Storm" to bring an action for false light invasion of privacy. They held that "[a] cause of action for false light invasion of privacy is "strictly personal and may be asserted only by the
} 
owner to protect the vision and portrayal of characters, even in situations where the subject has passed.

It is important to note that while I advocate the position that intellectual property law is well equipped to handle the issues of false portrayals in nonfiction works and that the established frameworks available within intellectual property law would be sufficient, I am not necessarily advocating the position that the Copyright Act should govern the issues presented herein. My discussion and application of the Copyright Act is simply an illustration of how intellectual property law provides a working framework that may provide alternative solutions to the issue of false portrayals.

Second, treating the portrayal and reputation of individuals as intellectual property will also defeat a glaring issue in the current approach to resolving these conflicts. Currently, there is no distinction between a defamation claim and a right to privacy claim, and there is also confusion over whether the claims are coterminous. ${ }^{65}$ As a result, courts struggle to apply the correct standards and defenses, and "waste judicial resources untangling genuine claims of defamation from duplicative false light claims." ${ }^{66}$ Conversely, the court is comfortable with the First Amendment and has extensive knowledge and precedent that relates to the rights it protects. This may explain the court's emphasis on First Amendment rights in the close cases. Until there is clarity in this area or until an alternative solution, such as the one I advance herein, is established, the courts will continue to favor the protection of First Amendment rights to the detriment of the owner and the individuals portrayed in the films.

person who is the subject of the challenged publication.' Relatives of a deceased person have no such cause of action 'regardless of how close [their] personal relationship was with the deceased"').

${ }^{65}$ Hallander, supra note 14 , at 282.

${ }^{66} \mathrm{Id}$. at 277. 
I propose that while intellectual property law should serve as the framework for resolving issues of false portrayals, the courts' consideration of First Amendment rights should not be replaced. However, an analysis of First Amendment rights should be reviewed in conjunction with the following factors: intentions of the original grantor of rights as expressed in the negotiations and contracts, the contractual agreement of the film production company with any of the subjects portrayed in the film, the actual effects of the inaccurate portrayal, and the production company's justification of the inaccuracy.

Finally, standards must be established for determining whether an individual has been harmed and what damages should be awarded. In assessing whether a portrayal harmed an individual, the courts should not punish a film production company for minor changes or additions. Examples of minor changes should include logistical changes - a change or addition to a conversation for purposes of compressing a long detailed story into one film. This permits the production company to exercise their First Amendment rights and artistic expression while still protecting the subjects of the film.

However, changes in the facts for embellishment purposes or for purposes of emphasis or dramatization should be assessed more critically. A film production company should be held liable for attacking or changing an individual's character. The burden of proof would be on the production company. Thus, any documentary or testimonial evidence which suggests that the adaptation negatively portrays the subject or changes the individual's character should weigh heavily in favor of finding the production company liable for the harm caused to the subject. In addition, the production company should be liable for exhibiting facts in a manner that, while individually true, are not true as a compilation. Again, the burden of proof would fall on the 
production company. The courts should ensure that the underlying facts of the entire story and the reputation of the subject remain unchanged.

In the event that the court holds that the subject was harmed, it should award compensatory damages that reflect a portion of the film production company's gross revenue from the film. The court has discretion to determine what constitutes a just amount. Awarding damages based upon the gross revenue will prevent a production company from being enriched at the expense of an individual's reputation. In addition, the court should mandate the film production company to either edit the inaccurate portions or include a disclaimer of the inaccuracies on all copies of the film, in a form that is acceptable to the subject. This requirement will deter film production companies from inaccurately portraying the characters and it will also compensate the victims. Furthermore, enforcement of the compensatory award and the order to edit the film or include a disclaimer will not be difficult for courts to apply nor will it burden the courts.

\section{Conclusion}

In conclusion, the lack of protection and remedies afforded to the characters in nonfiction films is harmful to those individuals. Furthermore, permitting the film production companies to maintain nearly unbridled ability to change or adapt factual stories does not serve a valid purpose that outweighs the harm or the potential harm to the subjects. The courts should seek to eliminate or mitigate the harm that is caused by the film production companies through intellectual property law. The goals addressed in this note can be achieved without sacrificing or interfering with First Amendment rights and will benefit all parties involved. 